\title{
Some High Value Medicinal Plants of Khumbu Region Nepal
}

\author{
Deepa Shree Rawal, Jaishree Sijapati, Neesha Rana, \\ Prabina Rana, Anjana Giri and Sangita Shrestha \\ Nepal Academy of Science and Technology, Khumaltar, Lalitpur, Nepal
}

\begin{abstract}
Visualizing the present biodiversity status of Nepal, an integrated approach comprising of biodiversity documentation, bio-prospecting, sustainable utilization and conservation has become an urgent need. Realizing the importance of medicinal plants altogether 45 plants were collected from Khumbu region with the altitudinal variation of $2582 \mathrm{~m}$ to $4470 \mathrm{~m}$. Among the collected plant species 12 have been characterized as highly valuable. The important biochemical constituents and morphology of these plants have been described in this paper.
\end{abstract}

Key words: Himalayan region, Khumbu, medicinal plants, morphological characters.

\section{Introduction}

Medicinal plants are second most valuable bio-resources of Nepal after water resources. Many highly demanded and globally important medicinal plants such as Swertia spp., Neo-picrorhiza scrophulariiflora, Podophyllum hexandrum, Taxus wallichiana, Podocarpus sp. etc. are harbored in various geoclimatic region of Nepal (Polunin $\&$ Stainton 1984, Press et al. 2000). The total number of medicinal and aromatic plants reported in Nepal varies according to various authors (DPR 1970, 1984; Malla \& Shakya 1999, Baral \& Kurmi, 2006). The compilation of Medicinal and Aromatic plant database of Nepal was published in 2000 (Shrestha et al. 2000), which listed 1624 species of medicinal plants. Most recently, Ghimire (2008) reported 1950 species of medicinal plants in Nepal.

According to recent estimates by the World Health Organization, more than 3.5 billion people in the developing world rely on plants as components of their primary health care (www. fao.org). High value medicinal plants have been the basis for modern allopathic drug development while the use of indigenous drugs from plant origin form major part of complementary and alternative medicines in the form of herbal drugs and Ayurvedic medicines. Many such high value medicinal plants have been equally used in other forms of alternative medicines such as Chinese, Tibetan and Homoeopathic medicine (Li et al. 1997, Dhama \& Dhama 1996). Therefore, the production, consumption and international trade in medicinal plants and phytomedicines are growing and expected to grow quite significantly in future.

Himalayan region of Nepal is one of the major store houses of various high value medicinal plant species. Most of such valuable plants grow in wild conditions as natural components of vegetation of particular region. The necessary plant material (roots, leaves, bark, etc) are collected and sold by the local people to the traders, industries and exporters purchase them from traders. Since there is no scientific system of collecting and regenerating these plants, several such high value plants have either been completely lost or have become endangered. In this scenario, handling of Nepalese medicinal biodiversity should involve 
an integrated approach comprising of well documentation, their sustainable utilization and conservation.

Conventionally, macroscopic (morphological) and microscopic characters including anatomy, cytology and chemical profiling techniques such as thin layer chromatography (TLC) and high performance thin layer chromatography (HPTLC), gas chromatography (GC), high performance liquid chromatography (HPLC), etc are being used for characterizing genotypes and chemotypes (Joshi et al. 2004). Such studies can produce deep level insights for conservation and sustainable utilization of high value medicinal plant biodiversity of Nepal.

Present study on high value medicinal plants of Khumbu region was formulated for the exploration, documentation and characterization of high value medicinal plants of Khumbu region in order to devise prospects of such plants for long-term sustainable utilization and conservation.

\section{Materials and Methods}

Field survey was carried out during May, 2007 at Khumbu region of Nepal, for the ecological, anatomical study and for the collection of herbaria for the morphological studies as well as collection of anatomical and DNA samples. Altitude, longitude and latitude readings of the plant collection sites were taken by using geographical positioning system (GPS). The collected plants were properly dried and mounted for further identification.

Herbarium specimens were prepared for the collected high value medicinal plants. Morphological identification of the specimens was carried out consulting taxonomic experts and using various taxonomic literatures (Polunin \& Stainton, 1984, Press et al.2000). Again, the specimens were compared with previously identified herbaria in National Herbarium and Plant Research Laboratory,
Godawari and Plant specialists from Natural History Museum, Swoyambhu.

\section{Description of major vegetation}

The vegetation pattern from Lukla (2800) to Jorsalle (2400) to Namche (3400) comprises the canopy vegetation of Abies spectabilis $D$. Don, Pinus roxburgii Sarg., Rhododendron arboretum Smith, Tsuga demosa D. Don, Pinus wallichiana A.B. Jacks etc. In case of the shrubby vegetation plants like Rhododendron triflorum Hook.f, Juniperus indica Bertol, Juniperus recurva Buch. Ham. ex D. Don, Berberis aristata Hook. F. \& Thomson, Berberis erythroclada Ahrendt, Zanthoxylum nepalense $D C$, Cotoneaster microphyllus Wallich.ex Lindley, Rubus ellepticus Smith, Utrica dioca $L$ were quite common. The ground vegetation consisted mostly of plants like Euphorbia wallichi Hook.f, Artemisia sps., Viola $s p$., Plantago ersoa Wall, Primula $s p$.

Above Namche along Syangboche and Khunde Khumjung trail (around 3400-4000). The common vegetation comprised of Juniperus sp., Rhododenron anthopogan D.Don, Rhododendron wightii Hook..f as well as different species of Berberis. Around $4000 \mathrm{~m}$, Juniperus indica Bertol were present and above $4,000 \mathrm{~m}$, where conditions are drier, along with dwarf rhododendrons and Cotoneasters, Ephedra girardiana Wall ex Stapf, shrubby Potentilla sp, willow Salix sp were found.

The shrub layer diminishes as conditions become cooler and above $5000 \mathrm{~m}$, other dwarf shrubs in the dry valley upland, include horsetail Ephedra gerardiana Wall ex Stapf, Juniperous indica Bertol and Potentilla sp. Above this and up to the permanent snow line at about $5,750 \mathrm{~m}$, plant life is restricted to lichens, mosses and dwarf grasses.

\section{Results}

Altogether, 45 medicinal plants were collected from the research site. Of them, 12 have been short listed as being high value species for further detail study (Table 1). The selection has been based on IUCN category, CITES list, DPR list, IDRC list and other relevant literature. 
Deepa Shree Rawal et al./Some High Value Medicinal Plants.

Table 1. List of high value medicinal plants collected from the Khumbu Region with geographical positioning

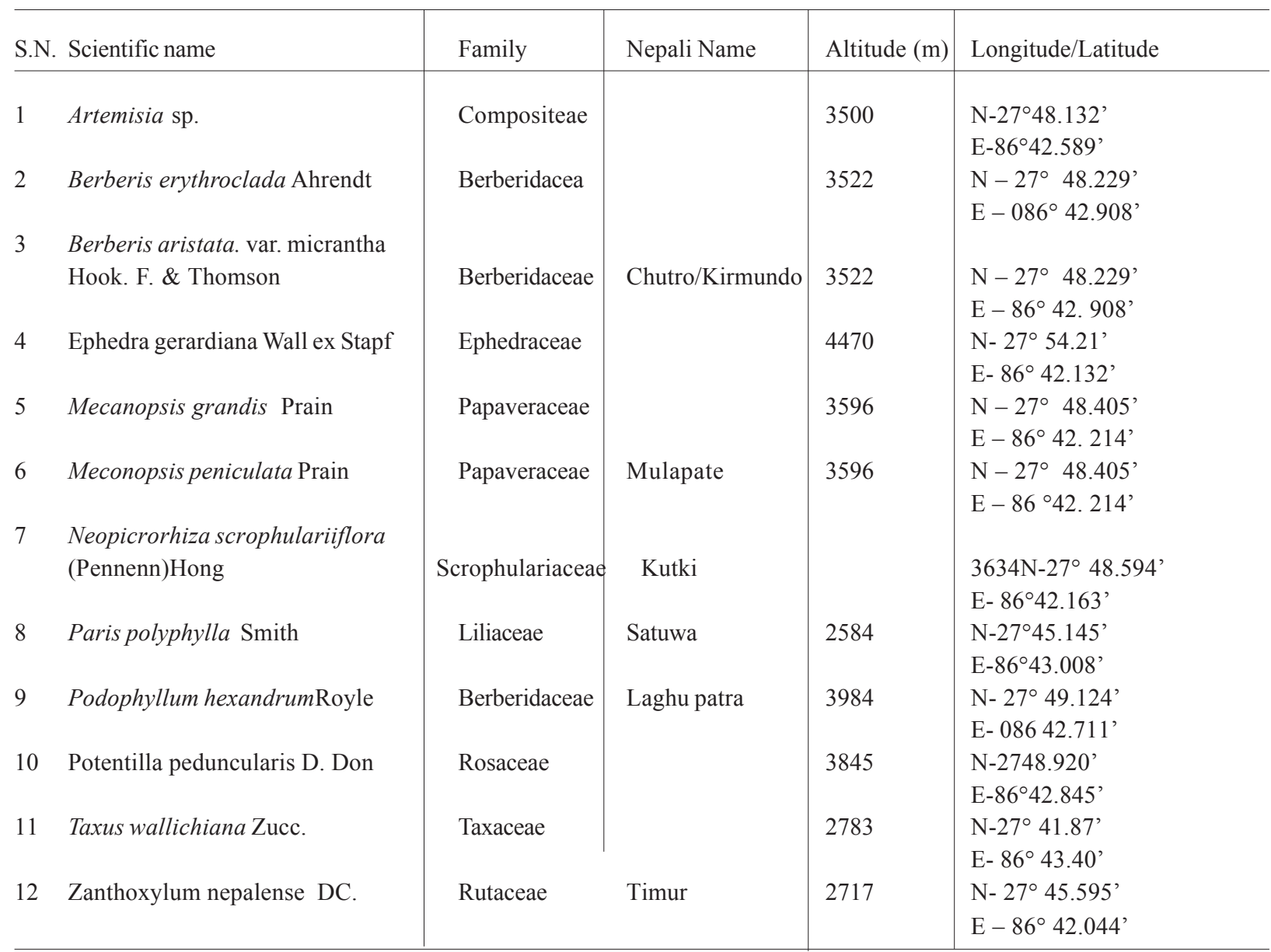

\section{Morphological description and important chemical constituents}

\section{Abies spectabilis (D. Don) Mirb}

Tall evergreen, coniferous tree about $50 \mathrm{~m}$ in height. Leaves sessile, linear, flattened, leathery, dark green above and whitish beneath with incurved margins, notched at the apex. Flowers unisexual, female cones solitary, situated a little below the tips of shoots, dark purple when young and brown at maturity with broad fan shaped scales, erect cylindrical, $10-20 \mathrm{~cm}$ long and 4-7.5 $\mathrm{cm}$ broad. Male cones usually clustered, yellowish and ellipsoid,5cm long. Cones: April- May. (Plate 1)

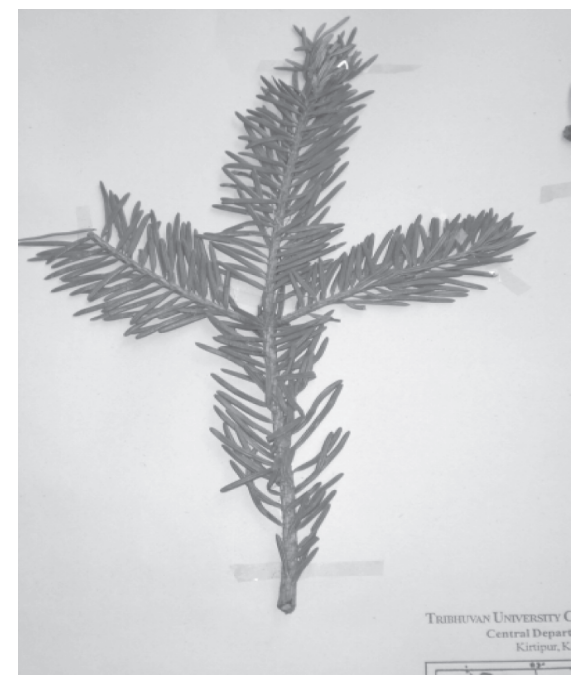

Plate 1 - Abies spectabilis 
Leaves produce essential oil which contains mainly á and â- pinene, camphene, lemonene, bornyl acetate (DPR 2007).

\section{Berberis aristata DC}

Spiny shrub about $3 \mathrm{~m}$ high. Leaves sub-sessile, clustered, $2-7 \mathrm{~cm}$ long, $0.5-2 \mathrm{~cm}$ wide, ovate with trifid spines, entire or spinuous dentate, smooth, base tapering. Flower stalked, yellow, in dropping racemes. Fruit ovoid, blue black when ripe. Flowering: March June. Fruit: July - November. (Plate 2)

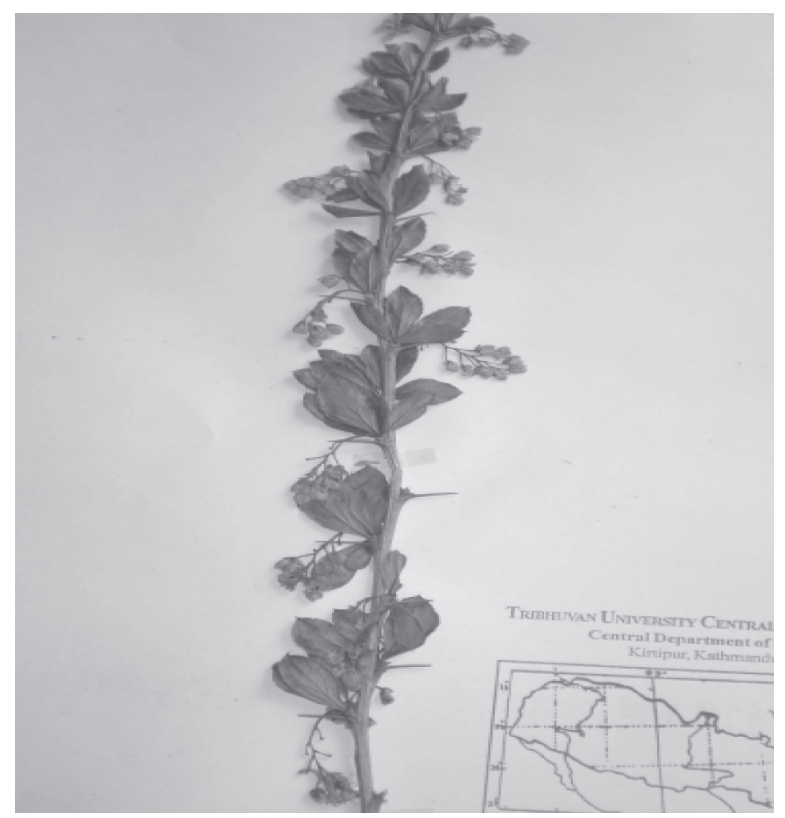

Plate 2-Berberis aristata DC

Root's bark contain berberis aristratin, berberine, berbamine (DPR 2007).

\section{Berberis erythroclada Ahrendt}

Much branched spiny shrub, about $1 \mathrm{~m}$ high, branches grooved, shiny dark red. Leaf stalks, $1-2 \mathrm{~cm}$ long ovate, margin dentate. Flowers yellow, solitary, on a slender stalk. Fruit red. Flowering: June-July. (Plate 3)

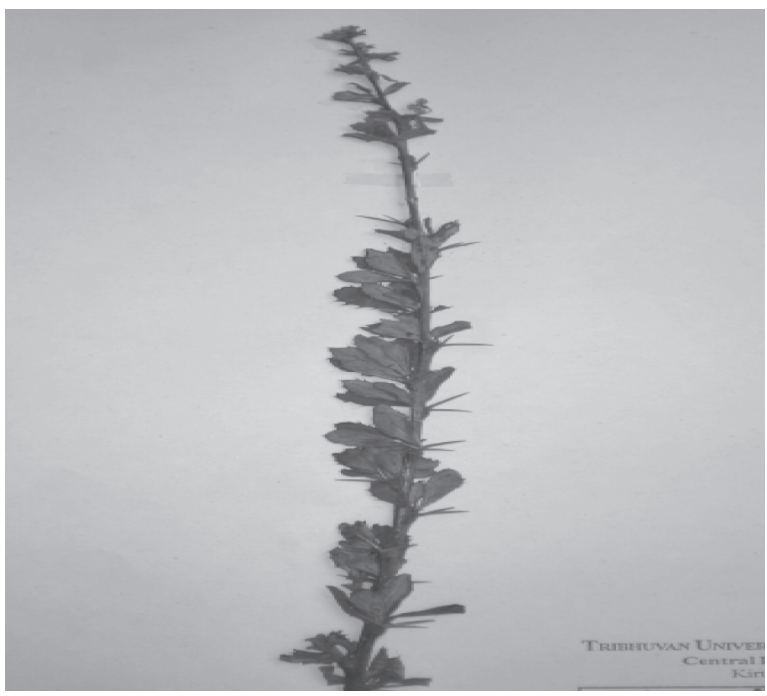

Plate 3- Berberis erythroclada

Root bark contains berberis aristratin, berberine, berbamine (DPR 2007).

\section{Ephedra gerardiana Wall. ex Stapf}

A rigid tufted gymnospermous shrub about $1 \mathrm{~m}$ high. Stem much branched whorled spreading. Leaves reduced to 2 toothed sheaths. Branches smooth, slender, green and jointed. Plants are dioceious, male flower ovate, 6 $8 \mathrm{~mm}$ long with $4-8$ flowers. Female cones usually solitary and yellowish, ovules ovoid, 7-10 mm surrounded by fleshy red succulent persistent bracts enclosing two seeds. (Plate 4)

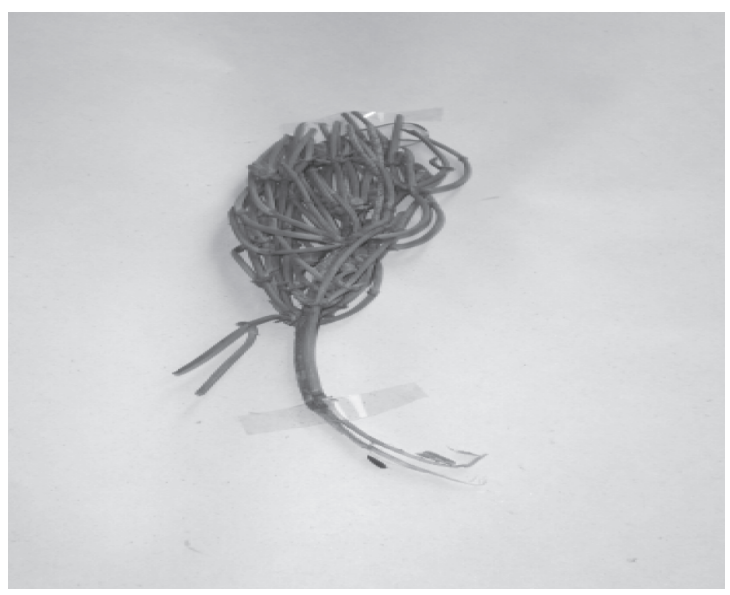

Plate 4- Ephedra gerardiana 
Aerial parts contain ephedrine, ephedroxyne, ephedrine and pseudoephedrine. (Husain et al. 1992).

\section{Meconopsis grandis Prain}

Polycarpic herb up to $1 \mathrm{~m}$ high. Tap root narrowly dauciform or root system fibrous. Stems leafy, basal part coverd with apprised bristly, membranous persistant leaf sheats, clothed with refouse, deflelxed,3-7mm long yellow bristle. Leaf elliptic oblanceolate, long petioles, apex acute, base cuneate or shortly attenuate, margins entire or with several broad teeth. Flowers blue, solitary on axils of upper most leaves. Seed reniform. Flowering: June to July. Fruiting: August - September. (Plate 5)

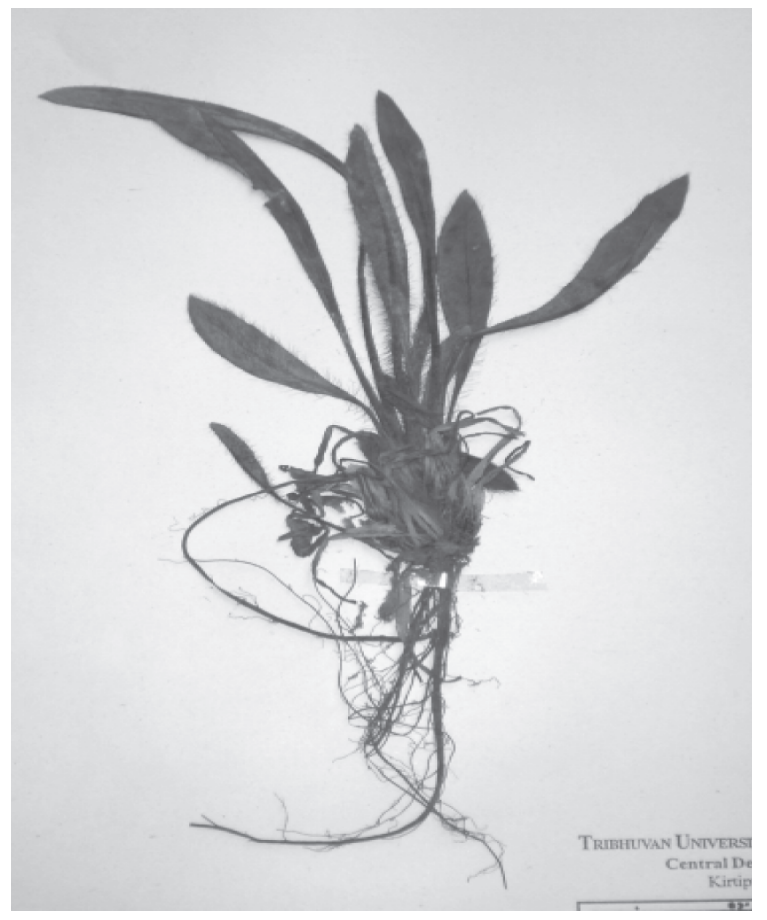

Plate 5- Meconopsis grandis

Phytochemical constituent's are cyanidin 3-malonylsambubioside 7-glucoside as the anthocyanin. They also contain large amounts of kaempferol 3-gentiobioside and very small amounts of kaempferol 3-xylosylgentiobioside. The ratio of flavonol to anthocyanin was found to be 5.6:1, suggesting that the flavonol plays a role as a copigment in the blueing of Meconopsis flowers, rhoeadine alkoliod in traces (Kosaku et al. 1996).

\section{Meconopsis peniculata Prain}

Monocarpic herb $1.8 \mathrm{~m}$ tall, tap root dauciform or narrowly elongated. Stems moderately bristly covered with golden yellow soft hairs. Leaves linear-oblong on outline, deeply pinnatifid or pinnatisect at the base densely clothed with same type of hairs like in stems, segments ovate-oblong, base spatulate, apex acute to obtuse margin coarsely serrate. Flowers solitary terminal or axillary, numerous pendulous, borne singly in upper part in 2-6 flowered lateral cymes in lower part. Ovary sub globose, ellipsoid or ovoid densely covered with hairs. Flowering :June - August, Fruiting time : September- October. (Plate 6)

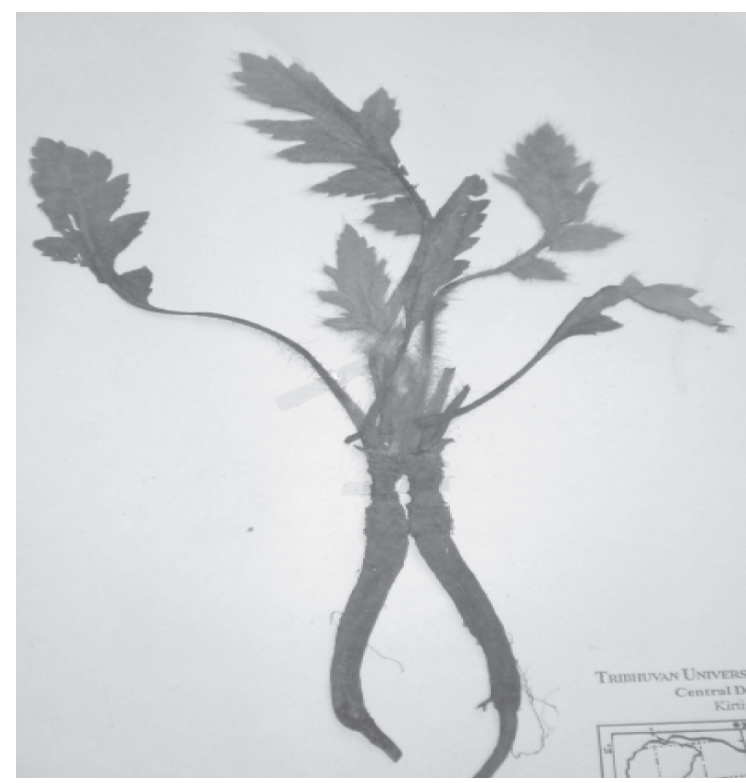

Plate 6- Meconopsis peniculata

Phytochemical constituents are alkaline phosphatases, glucose 6-phosphate dehydrogenase and malate dehydrogenase (Irshad et al. 1993) Papaverrubin A, B,C, D E, rhoeadine alkoliod in traces (Arnold et al. 1986 ).

\section{Neopicrorhiza scrophularifflora (Pennell) Hong}

A prostrate herb about $10 \mathrm{~cm}$ high with perennial woody rhizome covered with old leaves at the base. Leaves sub sessile aggregated at the base, each leaf $2-6 \mathrm{~cm}$ long and $0.5-1.2 \mathrm{~cm}$ wide, acuminate, serrate, stalked 
and winged, oblanceolate. Flowers dark blue purple, flowering: July - August in a dense terminal spikes arising from a rosette of conspicuously toothed leaves, spikes $5-10 \mathrm{~cm}$ long, Fruits capsule; October November 6-10mm, Rhizome is bitter.(Plate 7)

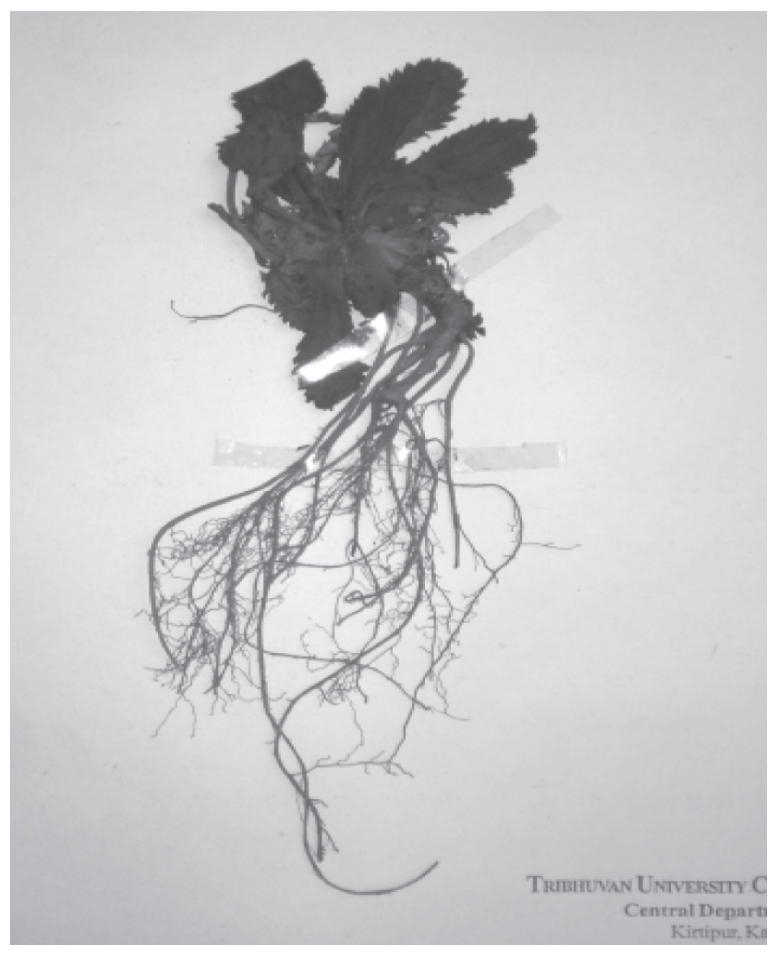

Plate 7- Neopicrorhiza scrophulariflora

Phytochemical constituents contain Kutkin (glucosidal), kurrin (a non bitter product), kutkiol(alcohol), kutkisterol.(Watanabe et al. 2005), Rhizomes and roots contain picroside I, picroside II, kutkoside, minecoside, phenol glycoside (picein and androsin) and 4 hydroxyacetophenone.(Anynomous 2002) Kutkiol (an alcolhol), pocrorhizin, pocrorhizitin, picroside, picroliv, kuthoside, androsine, aucubin, catalpol, valinic acid and kutkisterol (Kunwar 2006).

\section{Paris polyphylla Sm}

The herb is about $60 \mathrm{~cm}$ high. Leaves stalked, in a whorl at the top of the stem, $5-16 \mathrm{~cm}$ long, $1.5-4 \mathrm{~cm}$ wide, lanceolate, long-pointed, dark green. Flowers solitary, Flowering time: April-May. (Plate 8)

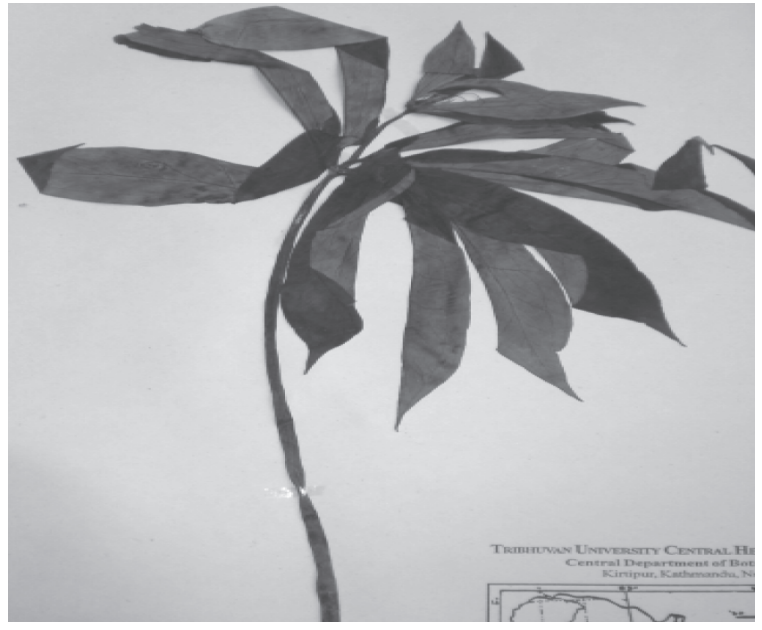

Plate 8- Paris polyphylla

Rhizome contains pariphyllin A, pariphyllin B, parsterone, pollyphylin D, and trillin (Buckingham 1994).

\section{Podophyllum hexandrum Royle}

An erect perennial herb about $15-40 \mathrm{~cm}$ tall. Leaves usually two, deeply three lobed. Long stalked, orbiculate to cordate. Lobes obovate, acuminate, serrate. Flowering time May - June, cup shaped, 2-4 cm across, large white or pale pink. Fruiting time: July - September, ovoid, $2.5-5 \mathrm{~cm}$ long, scarlet when ripe.(Plate 9)

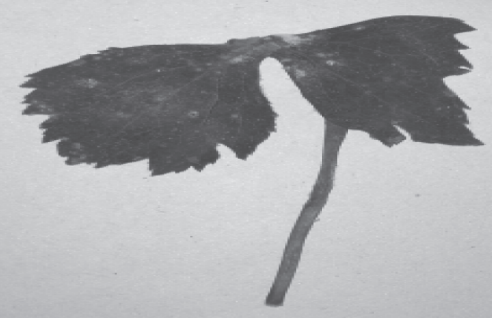

Plate 9- Podophyllum hexandrum

Podophyllotoxin,4'-dimethyldesoxy podophylotxxin, " $\alpha$ and $\beta$ pellatin, deoxypodophyllo toxin, 
podophllotoxone, isopicropodophyllone, 4'demethyldesoxy podophyllotoxin, 4'demethyldesoxypodophllotixe are the biochemical chemical constituents of this plant (Husain et al. 1992).

\section{Potentilla peduncularis D. Don}

Perennial, herbaceous plant about $30 \mathrm{~cm}$ in height, rootstock stout, covered with old leaf bases. Leaves uniformly pinnate about $20 \mathrm{~cm}$ long mostly basal covered with silvery hairs appear white at beneath. Flowers yellow, corymbs, flowering and fruiting time July - November.(Plate10)

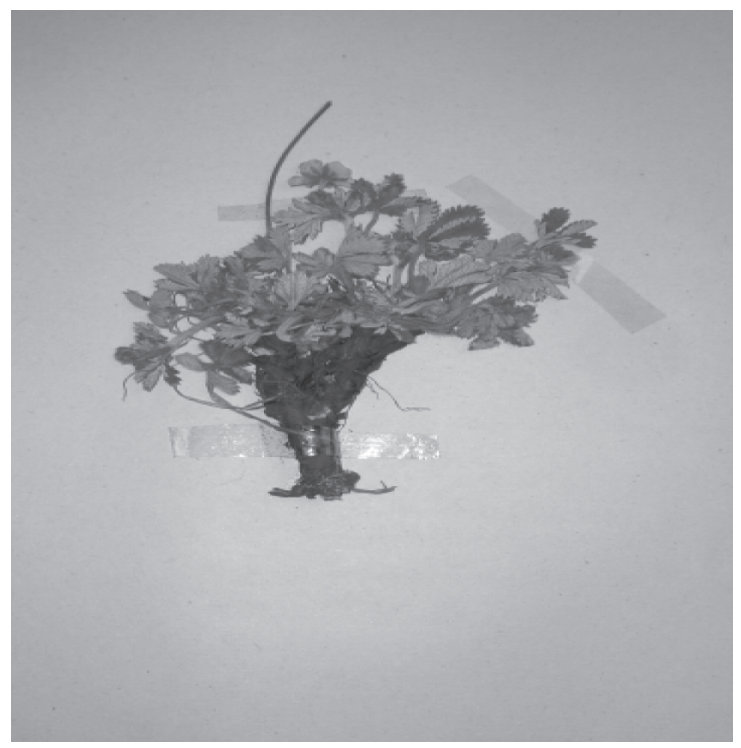

Plate 10- Potentilla peduncularis

Most of the pharmacological effects can be explained by the high amount of tannins and to a lesser extent by triterpenes, present in all plant parts. Polyphenols and flavonoids are also present in this plant (Micha ${ }^{3}$ et al. 2009).

\section{Taxus wallichiana Zucc}

Evergreen much branched coniferous tree nearly $30 \mathrm{~m}$ tall. Bark reddish brown, rough, exfoliating in irregular papery scales. Leaves linear, short- stalked, flat, acute, distichous, shiny dark green above, rusty beneath and narrowed towards the base, $2-3.5 \mathrm{~cm}$ long and $3 \mathrm{~mm}$ broad. Flowers unisexual, male flowers in short stalk, globose catkins in axils of leaves; female flowers solitary, axillary, green. Cones yellowish, axillary. Fruits or seed cones are red fleshy, $8 \mathrm{~mm}$ in diameter. Seeds are olive green.(Plate 11)

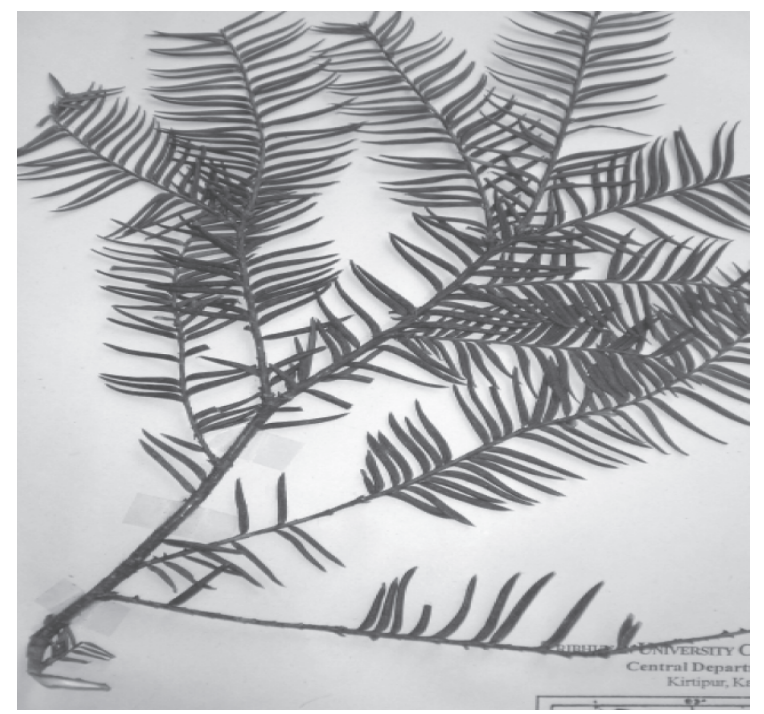

Plate 11- Taxus wallichiana

Biochemical constituents contain taxine alkaloids and taxol (Joshi \& Joshi 2001).

\section{Zanthoxylum nepalense Babu}

Shrub with corky bark and numerous straight spines. Leaves stalked pinnatifid, rachis winged, leaflet short stalked 1-3 cm long, ovate, dentate, gland dotted, flower yellowish, fruit a capsule, globose red and wrinked. Flowering time: May -June. (Plate 12)

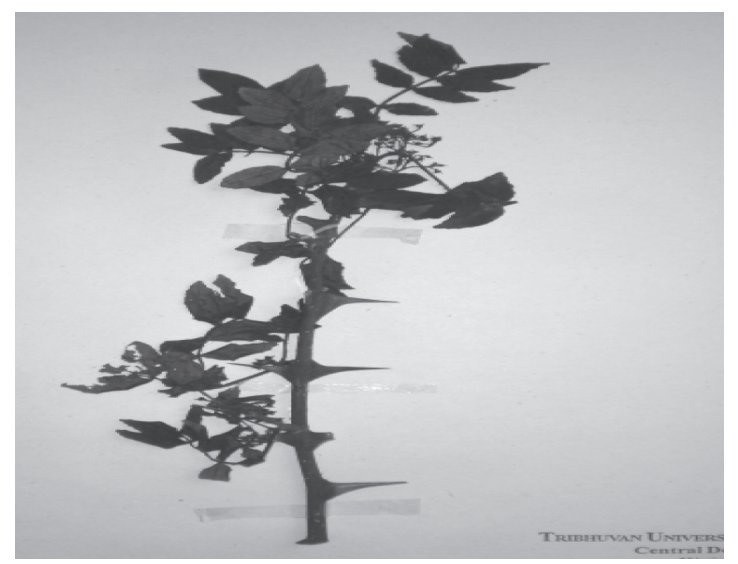

Plate 12 - Zanthoxylum nepalense

Tannic acid, gallic acid, starch, mineral salts and mucilage from the rhizome contain (Anonymous, 1994) biochemical constituents. 


\section{Discussion}

Several collected plants were found to have different medicinal uses in different alternative medicines such as Tibetan medicines, herbal drugs have been homoeopathy (Alam et al. 2008, Dhama \& Dhama, 1996), many others have been mentioned in ethnomedicinal literatures (Ghimire 1999. Rajbhandari, 2001, Joshi \& Joshi, 2001, Bhattarai et al., 2006, Rajbhandari et al. 2007, Bhattarai et al. 2008, Ghimire 2008).

P. hexandrum, Himalayan May apple, is recognized for its anticancer properties (Alam et al. 2008) and has been employed in the treatment of cancer (Prakash et al. 2005). It has been extensively exploited in traditional Ayurvedic system of medicine for treatment of a number of ailments like Condyloma acuminata, Taenia capitis, monocytoid leukemia, Hodgkins disease, non-Hodgkin's lymphoma, cancer of brain, lung, bladder and venereal warts. Utility of $P$. hexandrum has also been reported against constipation, cold, biliary fever, septic wound, burning sensation, erysipelas insect bite, mental disorders, rheumatism, plague and to provide symptomatic relief in some of the allergic and inflammatory conditions of skin. The radio-protective effect of hydroalcoholic extracted material from the rhizome of $P$. hexandrum was studied in mice exposed to lethal $\Upsilon$ radiation $(10 \mathrm{~Gy})$. The extract was found to restore the hemoglobin content $\left(\begin{array}{lll}14.73 & 0.33) \text { and }\end{array}\right.$ total leukocyte count (TLC) (4166.66 \pm 0.02$)$ in lethally (10 Gy) $\Upsilon$-irradiated mice on the 15 th day in comparison to the radiation control mice (Arora et al. 2007).

Similarly, various species of Berberis are reported to have various medicinal properties. Berberis aristata has been reported to have wound healing properties (Biswas \& Mukharjee 2003). It produces a bitter tonic, which is anti periodic and diaphoretic. The chief constituents are those of berberis bark, the principle being the alkaloid Berberine (Internet visit 2007; www. botanical.com). Aqueous extract of $B$. vulgaris has antihistaminic and anticholergenic activity in guinea pig ileum (Shamsa et al. 1999). Berbamine, an ingredient of Berberis is widely utilized in Chinese Folk Medicine as a source of leukogenics, anti-arrhythmic and anti-hypertensive. In recent years, the immunosuppressive effect of berbamine has been demonstrated (Luo et al. 1998). Therefore, bioprospecting of important biomolecules in Nepalese
Berberis species can be a prospective research area in future.

N. scrophulariflora (Kutki) is in high demand in and outside of Nepal for its valuable rootstocks. It furnishes the drug, picrorhizin, obtained as dried rhizomes and roots; which is used as an adulterant of or as a substitute for Indian gentian (Gentiana kurroo). The rhizomes of this Himalayan perennial herb are used in several traditional medicine systems to treat a wide variety of ailments. Kutki is widely distributed in the Himalayas (3000-5000 m), occurring in Pakistan, India, Nepal, Bhutan and Southern China (Traffic international 1999, Press et al. 2000).

Although little is known about biochemical specificities of Himalayan medicinal plants, some evidences suggest that such plants offer great potential for discovery of novel molecules and new sources of active compounds, mainly because of environmental stress to which they are subjected (Ghimire 2008).In mountains, plant secondary compounds exhibit patterns of variation in relation to stress associated with elevation, which relates to plant competition for resources, defense strategies against herbivores and pathogens and harsh climate (Iwashina et al. 2004). Concentration of active phytochemical constituents of some Himalayan medicinal plant species have been reported to be high in populations growing at higher altitude as compared to populations growing at the lower altitude (Mikage et al. 1987).

Regarding the conservation and sustainable utilization of high value medicinal plant species of Nepal in the changing scenario of environmental changes, an integrated approach needs to be followed. For rational and sustainable utilization of valuable medicinal plant species, conventional plant breeding techniques as well as biotechnological techniques need to be integrated to increase productivity and long term conservation. Considering the present scenario on advancement in biotechnology, in addition to conventional techniques of biodiversity characterization, detail molecular characterization also should be incorporated. So that the technique will further help during intellectual property rights (IPR) protection, devise authentication technique, in revealing taxonomic and evolutionary relationships for bioprospecting. 
Deepa Shree Rawal et al./Some High Value Medicinal Plants.

\section{References}

Alam, A., P.K. Naik, P. Gulati, A.K. Gulati and G.P. Mishra. 2008. Characterization of genetic structure of Podophyllum hexandrum populations, an endangered medicinal herbs of Northwestern Himalayas, using ISSR-PCR markers and its relatedness with podophyllotoxin content. African Journal of Biotechnology 7(8): 1028-1040.

Anonymous, 1994. Ayurveda authentica: Helath in harmony with nature, CD ROM. Tata Interactive system (India) and Dabur Research Foundation Macromedia.

Anonymous, 2002. Indian Herbal Pharmacopea, (revised edition). Indian Drug Manufactucturers Association, 102, B Poonam Chambers, Dr Anneie Besent Rd, Mumbai, India.

Arora, R., S. Singh, R. Kumar, S.C. Puri, B.Krishna, M. S. Siddiqui, S.S. Lahiri, G.N. Qazi. 2007. Cytoprotective effect of Podophyllum hexandrum against Gamma radiation is mediated via Hemopoietic system stimulation and up-regulation of heme-oxygenase- 1 and the prosurvival multidomain protein $\mathrm{Bcl}-2$. Integrative Cancer Therapies 6(1):54-65.

Arnold Brossi, Richard Helmuth Fred Manske, Henry Lavergne Holmes, R. G.A. Rodrigo.1986. The Alkaloids: Chemistry and Pharmacology, Academic Press

Baral and Kurmi. 2006. A compendium of medicinal plants in Nepal. Publisher :Mrs. Rachana Sharma, 281 Maiju Bhal, Chabahil,Kathmandu, Nepal.

Bhattarai, S., R.P. Chaudhary and R.S. Taylor. 2008. Antibacterial activity of selected ethno-medicinal plants of Manang district, central Nepal. Journal of Theoretical and Experimental Biology 5 (1 and 2): 1-9.

Bhattarai, S., R.P. Chaudhary and R.S. Taylor. 2006. Ethno-medicinal plants used by the people of Manang district, Central Nepal. Journal of Ethnobiology and Ethnomedicine 2:41.

Biswas,T.K. and B. Mukherjee, 2003. Plant medicines of Indian origin for wound healing activity: A review. International Journal of Low Extreme Wounds 2(1):25-39.

www. botanical.com

Buckingham J. 1994. Dictionary of natural products, Vol. 7, Chapman and Hall, Boundary Row, London, UK.

DPR, 2007. Medicinal plants of Nepal (Revised). Bulletin of The Department of Plant Resources. No. 28, Ministry of Forest and soil Conservation.
DPR, 1970. Medicinal Plants of Nepal. Bulletin of The Department of Medicinal Plants No. 3. Department of Forestry and Plant Research, Ministry of Forests and Soil Conservation, Government of Nepal.

DPR, 1984. Medicinal Plants of Nepal. Bulletin of the Department of Medicinal Plants No. 10. Department of Plant Resources, Ministry of Forests and Soil Conservation, Government of Nepal.

Dhama, K.P.S. and S. Dhama 1996. Handbook of Homoeopathy. UBS Publication and Distributors, India.

Ghimire, S.K. 1999. Medicinal and aromatic plants in the Nepal Himalaya: Status, use, sale and Conservation. The Wildlife. 1(2): 42-52.

Ghimire, S.K. 2008. Medicinal plants in the Nepal Himalaya: Current issues, sustainable harvesting, knowledge gaps and research priorities. In: Medicinal plants in Nepal: Anthology of contemporary research. (Eds. P.K. Jha, S.B. Karmacharya, M.K. Chhetri, C.B. Thapa, and B.B. Shrestha). Ecological Society (ECOS), Kathmandu, Nepal. pp. 25-42.

Husain, A., O.P. Virmani, S.P. Popali, L.N. Mishara, M.M. Gupta, G.N. Srivastava, Z.Abraham, and A.K. Sing. 1992. Dictionary of Indian medicinal plants: Central Institute of Medicinal and Aromatic Plants, Lucknow, India.

Irshad, M.S. and R.B. Cherakuri 1993. Enzyme polymorphism analyses in three endangered species of Himalayan poppy, Meconopsis (Papaveraceae), Genetic Resource and crop evolution, Springer, Netherlands, 43(4).351-56.

Iwashina, T., Y. Omori, J. Kitajima, S. Akiyama, T.Suzuki, and H. Ohba. 2004, Flavinoids in translucent bracts of the Himalayan Rheum nobile (Polygonaceae) as ultraviolet shields. Journal of Plant Research 117:101-107.

Joshi, K., P.Chavan, D. Warude, and B. Patwardhan. 2004. Molecular markers in herbal drug technology. Current Science 87( 2):159-165.

Joshi, K.K. and S.D.Joshi. 2001. Genetic heritage of medicinal and aromatic plants of Nepal Himalayas, Buddha Academic Publishers and Distributors Pvt. Ltd. Nepal.

Kosaku, Takeda, Yamaguchi Shin, Iwata Keizo, Tsujino Yasuko, Fujimori Takane and Sayed Z. Husain. 1996. A malonylated anthocyanin and flavonols in the blue flowers of Meconopsis. Phytochemistry, 42(3): 863-865. 
Kunwar, R.M. 2006. Non-timber forest of Nepal. A sustainable management approach. Center for Biological Conservation (CBC) Nepal and International Tropical Timber Organization (ITTO) Japan.

Li, Z., W. Zhang, X.Hu, J. Diqing, C. Lurong, D. Baima and Y. C. Zhong. 1997. Pharmacognostic studies of Tibetan medicine da-li. Zhong Yao Cai 20(7):332-335.

Luo, C.N., X. Lin, W.K. Li, F. Pu, L.W. Wang, S.S. Xie, P.G. Xiao.1998. Effect of berbamine on Tcell mediated immunity and the prevention of rejection on skin transplants in mice, Journal of Ethnopharmacology 59(3):211-215.

Malla, S.B. and P.R. Shakya.1999. Medicinal Plants In: Nepal : Nature's Paradise. (Ed. Majupuria, T. C.), M. Devi, Gwalior, India. pp. 267-297

Micha $^{3}$, Tomczyk and Klaus Peter Latté 2009. Potentilla-A review of its phytochemical and pharmacological profile, Journal of Ethnopharmacology. 122, Issue 2, 18 184-204.

Mikage, M., H. Jin Takano, T. Tomimori and T. Namba. 1987. Studies on the Nepalese crude drugs (VII) on the variation in the morphological appearances and the alkaloids contents of the herbal stem of Ephedra gerardiana Wall. according to the differences in habitats. Shoyakugaku Zasshi. 41:209-214.

Polunin, O. and J.D.A. Stainton 1984. Flowers of the Himalaya. Oxford University Press, UK.

Prakash, H., A. Ali, M.Bala and H. C. Goel. 2005. Antiinflammatory effect of Podophyllum hexandrum (RP-1) against Lipopolysaccharides induced inflammation in mice. Journal of Pharmaceutical Science 8(1):107-114.
Press, J.R., K.K. Shrestha and D.A. Sutton 2000. Annotated checklist of the flowering Plants of Nepal. Natural History Museum, London.

Rajbhandari, K.R. 2001. Ethnobotany of Nepal. Ethnobotanical Society of Nepal.

Rajbhandari, M., R.Mentel, P. K. Jha, R.P. Chaudharay, S. Bhattarai, M.B.Gewali, N. Karmacharya, M. Hipper and U. Lindequist. 2007. Antiviral activity of some plants used in Nepalese traditional medicine.Complementary and Alternative Medecine. 1-6.

Shamsa, F., A. Ahmadiani, and R. Khosrokhavar. 1999. Antihistaminic and anticholinergic activity of barberry fruit (Berberis vulgaris) in the guineapig ileum. Journal of Ethnopharmacology 64(2): 161-166.

Shrestha, K.K., N.N. Tiwari, and S. K.Ghimire. 2000. MAPDON-Medicinal and aromatic plant database of Nepal. In: Proceedings of Nepal-Japan symposium on conservation and utilization of Himalayan medicinal resources. Department of Plant Resources, Ministry of Forest and Soil Conservation, Government of Nepal, Kathmandu, Nepal and Society of the Conservation and Development of Himalayan Medicinal Resources, Tokyo, Japan, pp. 53-74.

Traffic International, 1999. Implementation of the CITES appendix II listing of Jatamansi, Nardostachys grandiflora and Kutki Picrorhiza kurrooa. A report of the findings of research conducted by the traffic network under contract with the CITES secretariat.

Watanabe, T., K.R. Rajbhandari, K.J Malla and S. Yahara 2005. A Handbook of Medicinal Plants of Nepal. AYUR SEED, Life Environmental Institute, Japan Internet visits: www. botanical.com www. fao.org 